The Chittagong Univ. J. B. Sci., Vol. 4(1 \&2):153-163, 2009.

\title{
FACTOR INFLUENCING THE PRODUCTION AND PROPERTIES OF EXTRACELLUR PROTEASE FROM STREPTOMYCES BIKINIENSIS
}

\author{
S.U.H. WAHID, J.FERDOUSE AND M. N. ANWAR ${ }^{1}$ \\ Department of Microbiology, University of Chittagong, Chittagong-4331, Bangladesh.
}

\begin{abstract}
The actinomycete Streptomyces bikiniensis collected from laboratory stock culture, Department of Microbiology, University of Chittagong was found to be a protease producer. Effect of various culture conditions for the production of protease from $S$. bikiniensis and its properties were determined in the present study. The organism showed maximum protease yield at temperature $37^{\circ} \mathrm{C}$ with an initial culture, $\mathrm{pH} 7.0$ after 4 days of incubation period under stationary condition. The crude enzyme preparation exhibited highest activity at substrate (casein) concentration of $1.0 \%$ with a reaction time of $75 \mathrm{~min}$, at $40^{\circ} \mathrm{C}$ and $\mathrm{pH}$ 6.0. EDTA was found to a potent inhibitor of protease of the isolate while, 1,2epoxy-3-(P-nitrophenoxy) propane exhibited low inhibitory effect on the enzyme activity. The enzyme was partially purified by precipitation method using ammonium sulfate fractionation and the maximum amount of the enzyme was precipitated at $60 \%$ saturation.
\end{abstract}

Key words: Streptomyces bikiniensis, Protease activity, Factors influence. Crude enzyme

\section{INTRODUCTION}

Use of microorganisms in enzyme production is much more economical and environmentally friendly than conventional chemical synthetic methods. They can grow in a wide range of environmental conditions (Trevan 2003).Proteases are the most important enzymes in biotechnology, which occupy a pivotal position with respect to their application in both physiological and commercial fields. Proteases represent one of the largest groups of industrial enzymes and account for $60 \%$ of the total worldwide sale of enzymes (Rao et al.1998). Although proteases can be obtained from several sources including plant, animal and microorganisms, microbial proteases are preferred in view of their rapid

${ }^{1}$ Corresponding author:

$-21$ 
growth, ease of cultivation, purification and genetic manipulation. The microbial enzymes produced in the largest amounts on an industrial basis are the bacterial proteases, used as additives in laundry detergents (Madigan et al. 1997).Selection of a suitable isolate is the most significant factor in the protease production process. Cultural conditions greatly affect the growth and production of protease in different microorganisms (Rajakumar 1998, Das et al. 2005, Shafee et al. 2005, Ito et al. 2007).

In the present study, Streptomyces bikiniensis was a member of actinomycetes used for the production of protease. The effect of various culture conditions on the enzyme production was also evaluated.

\section{MATERIALS AND METHODS}

\section{Microorganism}

The previously isolated Streptomyces bikiniensis (2/BR8) was collected from laboratory stock culture of the Department of Microbiology, University of Chittagong, Chittagong. For the growth and preservation of the isolate sterilized starch casein agar (SCA) was used.

\section{Screening of the isolate for proteolytic activity}

The organism ability to hydrolyze protease enzyme was demonstrated by growing the organism in solid media containing different protein sources like skimmed milk casein, gelatin and egg albumin. Secondary screening of the isolate was made by measuring protease activity in liquid medium by quantitative method. For production of protease by the isolate, three different broth media, viz. Yeast Extract, Peptone, Dextrose broth (Amar and Halvorson 1975); Tryptone, Dextrose, Yeast Extract broth (Matta et al. 1997); and Gelatin, glucose, Yeast Extract broth (Shalinisen and Satyanarayana 1993) were used at temperature $37^{\circ} \mathrm{C}, \mathrm{pH} 7.0$ and with 5 days of incubation period.

\section{Measurement of enzyme activity}

Protease assay was done by the modified method of Hayashi et al. (1967) as followed by Meyers and Ahearn (1977). Three milliliters of culture filtrates, 3 $\mathrm{ml}$ of citrate phosphate buffer and $3 \mathrm{ml}$ of $1 \%$ casein were taken in a $25-\mathrm{ml}$ test tube. The test tube was placed in a water bath at $35^{\circ} \mathrm{C}$ for 1 hour. After reaction, 5 $\mathrm{ml}$ of $20 \%$ TCA was added to the reaction mixture to stop the enzymatic reaction. The solution was filtered by Whatman no. 540 (Ashless). From the filtrate solution, $1 \mathrm{ml}$ enzyme substrate mixture was taken into a test tube and $2 \mathrm{ml}$ of $20 \% \mathrm{Na}_{2} \mathrm{CO}_{3}$ was added to it. To this mixture $1 \mathrm{ml}$ of Folin Ciocalteu reagent was 


\section{PROTEASE FROM STREPTOMYCES BIKINIENSIS}

added and the contents of the tube were mixed well immediately. After 30 minutes $6 \mathrm{ml}$ distilled water was added to it and absorbance of the solution was measured at $650 \mathrm{~nm}$ in a Vis-UV spectrophotometer (LaboMedInp). The amounts of amino acids released were calculated from a standard curve using known concentrations of tyrosine. The enzyme activity was expressed in unit. One unit of enzyme was defined as the amount of enzyme that releases $1 \mu \mathrm{g}$ of tyrosine $/ \mathrm{ml}$ of crude extract/hour under the assay condition.

\section{Biomass yield}

The actinomycetes culture was filtered through Whatman no.1 filter paper. The filter cake was dried in oven at $80^{\circ} \mathrm{C}$ to a constant weight. The amount of biomass was calculated by subtracting the weight of filter paper. The yield was expressed as $\mathrm{mg} / \mathrm{g}$ of protein.

\section{Identification}

The isolate 2/RB8 was identified on the basis of its morphological, cultural and physiological characteristic. These characteristics were compared with standard description of Bergey's Manual of Determinative Bacteriology (Buchanon and Gibbons 1974).

\section{Optimization of culture conditions for maximum production of protease} Effect of incubation period

The effect of incubation periods on the maximum production of protease by the isolate was studied. The enzyme production was carried out in $50 \mathrm{ml}$ of selected medium in $100 \mathrm{ml}$ conical flasks and incubated for 48, 72, 96, 120, 144 and 168 hours. Then the culture filtrates were centrifuged at $8000 \mathrm{rpm}$ for $15 \mathrm{~min}$ at $4^{0} \mathrm{C}$ and the supernatants were used for the enzyme assay.

\section{Effect of temperature}

The culture medium was incubated at different temperature such as $10^{\circ} \mathrm{C}$, $27^{\circ} \mathrm{C}, 37^{\circ} \mathrm{C}$, and $45^{\circ} \mathrm{C}$ for enzyme production. The effect of temperature on biomass characteristic, biomass yield and protease production was recorded.

\section{Effect of medium $\mathrm{pH}$}

To observe the effect of medium $\mathrm{pH}$ on enzyme production, the medium was prepared with different $\mathrm{pH}$ values $(4.0,5.0,6.0,7.0,8.0$ and 9.0) and the incubation was carried out at $37^{\circ} \mathrm{C}$. The effect of medium $\mathrm{pH}$ on biomass characteristics, biomass yield and protease activity was recorded, 
Effects of stationary and shaking conditions on the production of proteases

To determine the effects of stationary and shaking conditions the inoculated media were incubated in both stationary and shaking condition (100 rpm) keeping other experimental conditions at optimal levels.

Determination of optimum conditions for the crude enzyme activity Effect of Reaction Time on Enzyme Activity

To ascertain the effect of reaction time on enzyme activity, the enzymesubstrate mixture was incubated at different reaction time i.e. 30, 45, 60, 75, 90 and 120 mins and its effect on enzyme activity were recorded.

\section{Effect of $\mathrm{pH}$ and Temperature}

The effect of $\mathrm{pH}$ on protease was determined by incubating the reaction mixture at $\mathrm{pH}$ value ranging from 4.0 to 8.0 using citrate phosphates buffer. The optimum temperature for enzyme activity was determined by conducting the assay at various temperatures from 35 to $55^{\circ} \mathrm{C}$.

\section{Effect of Substrate Concentration on Enzyme Activity}

To determine the effect of substrate concentration, enzyme activity was measured at different substrate concentration i.e. 0.5, 1.0, 1.5, 2.0, 2.5, 3.0\% of casein solutions and the effects on enzyme activity were observed.

\section{Inhibition of Protease Activity}

Stock solutions of $5 \%$ inhibitors were prepared by dissolving each as follows: PMSF (Phenylmethylsulfonyl fluoride) in 95\% ethanol; EDTA in distilled water; antipain in $1 \mathrm{mM} \mathrm{HCl}$ and 1, 2-epoxy-3-(P-nitrophenoxy) propane in Methanol with dilute alkali. The concentrated inhibitor solutions were diluted with water and mixed with an equal volume of enzyme solution. The enzymeinhibitor mixture was preincubated for 60 mins at $45^{\circ} \mathrm{C}$ and then protease activity was determined at optimum $\mathrm{pH}$. The inhibition of protease activity was calculated from the difference between the readings of the untreated sample minus the reading of treated sample, divided by the untreated sample reading, multiplied by 100.

\section{Enzymes purification}

The isolates were cultured in seven 250-ml Erlenmeyer's flask using 100 $\mathrm{ml}$ of the optimized broth medium. After incubation culture were filtrated and ammonium sulfate $(10,20,30,40,50,60$ and $70 \%$,) was added with constant stirring and left overnight at $4^{0} \mathrm{C}$. The precipitates formed were collected by centrifugation at $8000 \mathrm{rpm}$ for $20 \mathrm{~min}$ at $4^{0} \mathrm{C}$ and dissolved in $4 \mathrm{ml}$ of $0.1 \mathrm{M}$ phosphate buffer $\mathrm{pH}$ 7.0. 
PROTEASE FROM STREPTOMYCES BIKINIENSIS

\section{RESULTS AND DISCUSSION}

Streptomyces bikiniensis was collected from stock culture of the Department of Microbiology, University of Chittagong. The isolate was preserved and tested for its proteolytic activity. The isolate belonging to actinomycete group was a filamentous Gram-positive bacterium that forms branching filaments.

Screening of the isolates

Primary screening of the isolate was done by the boiled egg albumin degradation, gelatin hydrolysis and skimmed milk casein hydrolysis method. The isolate of actinomycete showed ability to degrade or hydrolyze these proteins. After primary screening, secondary screening was done by quantitative method. On the basis of its enzymatic activity in three different broth media, the bacterial isolate 2/BR8 was finally selected for detailed study.

\section{Identification of the selected isolates}

On the basis of the morphological, cultural and biochemical characteristics, the bacterial isolate was found to belong to the genus Streptomyces. It was provisionally identified as Streptomyces bikiniensis while compared with standard description of “Bergey's Manual of Determinative Bacteriology" $8^{\text {th }}$ ed (Buchanon and Gibbons 1974).

Optimization of culture conditions for maximum production of protease

Effect of incubation period on protease production

Fig:1 shows the effects of incubation period on enzyme production by the Streptomyces bikiniensis and maximum enzyme production was recorded after 4 days of incubation. The highest biomass yield $(90 \mathrm{mg} / \mathrm{g}$ substrate) was recorded after 5 days of incubation, associated with surface and sedimentary growth. Production of maximum extracellular protease after 120 hours of incubation period by actinomycete isolate was reported by Azeredo et al. (2004).

\section{Effect of incubation temperature on protease production}

The maximum protease production and highest biomass yield of the $S$. bikiniensis was recorded at $37^{\circ} \mathrm{C}$ (Fig:2). A wide range of temperature $\left(30^{\circ} \mathrm{C}\right.$ $55^{\circ} \mathrm{C}$ ) has been reported for optimum growth and protease production by Streptomyces sp.The results of the present study are in agreement to that reported by Patke and Dey(1998), Azeredo et al.(2004) and Dastager et al.(2008).

\section{Effect of medium $\mathrm{pH}$ on the production of protease}

$S$. bikiniensis showed maximum enzyme production at medium $\mathrm{pH} 7.0$ (Fig:3) but biomass characteristics of the strain varied with the $\mathrm{pH}$ of the medium. Fermor and Wood (1981), Kalisz et al. (1987), Shumi et al.(2004), and Rahman et 
WAHID ET AL.

al. (2005) reported that maximum production of protease occurred at neutral $\mathrm{pH}$ range (around $\mathrm{pH}$ 7.0). Our findings were in accordance with them.

\section{Effects of Stationary and shaking conditions on the production of proteases}

$S$. bikiniensis showed maximum protease activity $(83.59 \mathrm{U} / \mathrm{ml})$ at stationary condition (Fig:4). Abd Rahman et al. (2005) reported that shifting the culture from stationary to shaking condition decreased the protease production (6.0-10.0\% v/u).

Determination of optimum conditions for the maximum protease (crude) activity

\section{Incubation time}

During enzyme-substrate reaction, incubation time is an important factor for measurement of enzyme activity. Highest protease activity $(407.63 \mathrm{U} / \mathrm{ml})$ exhibited by the crude enzyme of the isolate 2/BR8 was achieved when incubated at $37^{0} \mathrm{C}$ for 75 mins (Fig:5).

\section{Temperature and $\mathrm{pH}$}

The enzyme production was carried out using casein as substrate at various temperatures ranging from $35^{\circ} \mathrm{C}$ to $55^{\circ} \mathrm{C}$ and $\mathrm{pH} 5.0$ to 8.0. The isolate showed maximum enzyme activity $\left(453.44 \mathrm{U} / \mathrm{ml}\right.$ ) at $40^{\circ} \mathrm{C}$ and $\mathrm{pH} 6.0$ (Fig:6). Maximum protease activity of extracellular protease of different species of Streptomyces at different $\mathrm{pH}$ and temperature has been reported by Saad and Hoda (1997), Kim et al.(1998), Azeredo et al. (2004), Seong et al. (2004) and Ramesh et al. (2009).

\section{Substrate Concentration}

Enzyme activity is markedly influenced by the concentration of substrate. In the present investigation, casein was used as substrate at different concentrations (ranged from 0.5 to $3.0 \%$ ). Maximum activity $(342.37 \mathrm{U} / \mathrm{ml}$ ) of the enzyme was found with $1.0 \%$ substrate concentrations (Fig:7).

\section{Inhibitors of protease}

EDTA exhibited maximum inhibitory effect on protease activity $(59.26 \%)$ followed by $40.21 \%, 47.55 \%$ and $25.34 \%$ inhibition of protease activity in the present of PMSF, antipain and epoxy propane respectively (Fig:8). Partial inhibition of protease activity of Streptomyces megasporus SDP4 in the presence of EDTA and PMSF was reported by Patke and Dey (1998).The protease activity of $S$. microflavus was strongly inhibited by PMSF was reported by Rifaat et al. (2006). 


\section{PROTEASE FROM STREPTOMYCES BIKINIENSIS}

\section{Purification of enzyme}

Enzyme was partially purified by precipitation method using 10 to $70 \%$ solid ammonium sulfate. The maximum protease activity $(382.44 \mathrm{U} / \mathrm{ml})$ of partially purified enzyme of the isolate $2 / \mathrm{BR} 8$ was recorded at $60 \%$ ammonium sulfate saturation (Fig:9)

From the above results, it can be concluded that the isolate $S$. bikiniensis (2/BR8) is a potent protease producer. The findings of this experiment could significantly contribute to the biotechnological application of microorganisms derived protease as a widely used enzyme. Further study of the strain improvement can be carried out to enhance enzyme production.

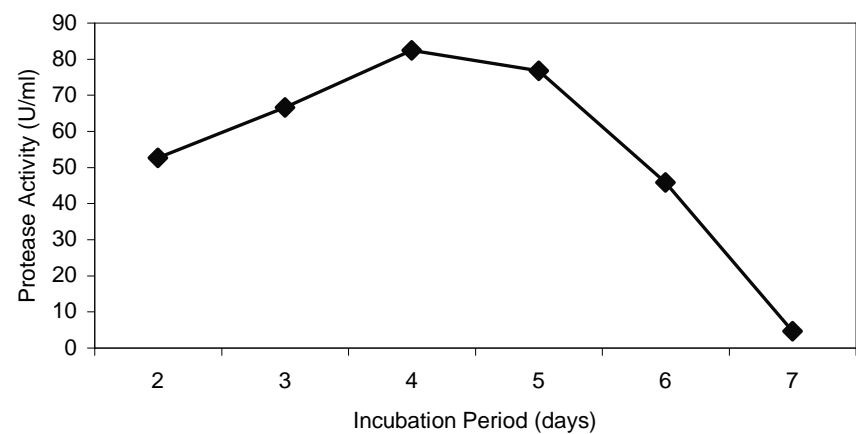

FIGURE 1. EFFECTS OF INCUBATION PERIOD ON THE PRODUCTION OF PROTEASE BY THE S.BIKINIENSIS (2/BR8).

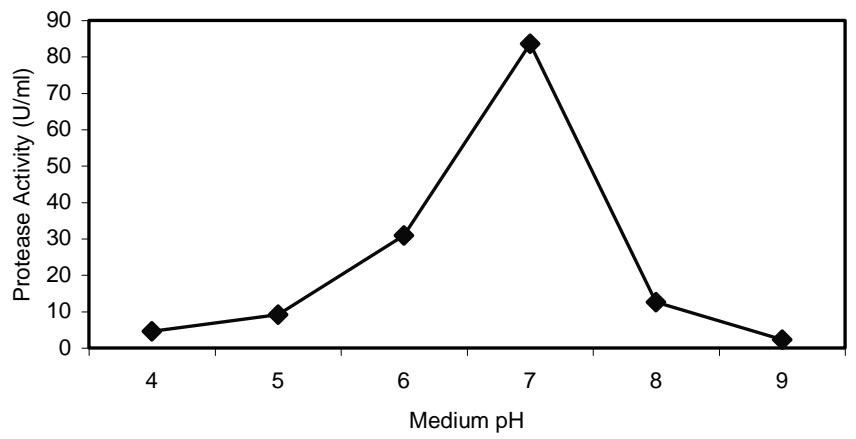

FIGURE 3. EFFECTS OF MEDIUM PH ON THE PRODUCTION OF PROTEASE BY THE $S$. BIKINIENSIS (2/BR8).

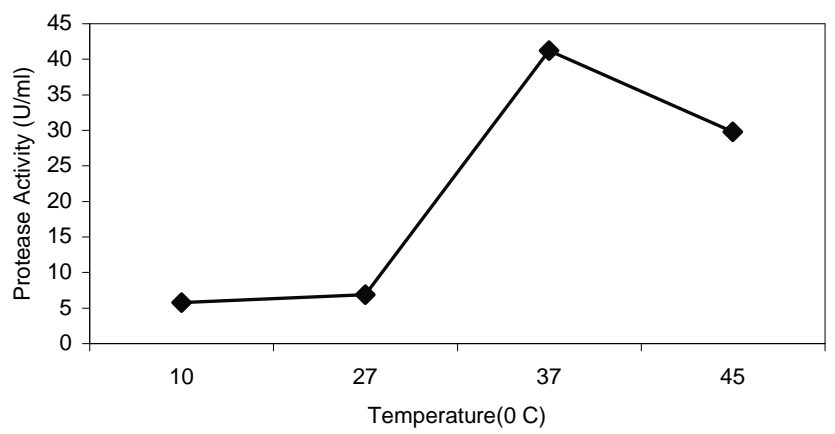

FIGURE 2. EFFECT OF TEMPERATURES ON PROTEASE PRODUCTION BY THE S.BIKINIENSIS(2/BR8).

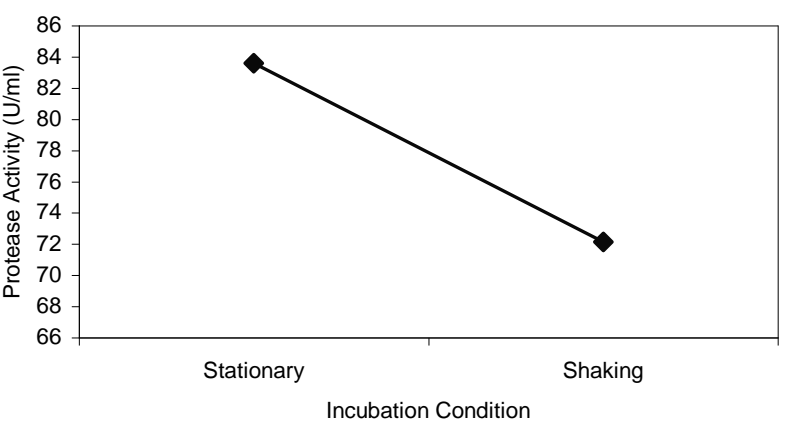

FIGURE 4. EFFECTS OF STATIONARY AND SHAKING CONDITION ON PROTEASE PRODUCTION BY THE S. BIKINIENSIS (2/BR8). 
WAHID ET AL.

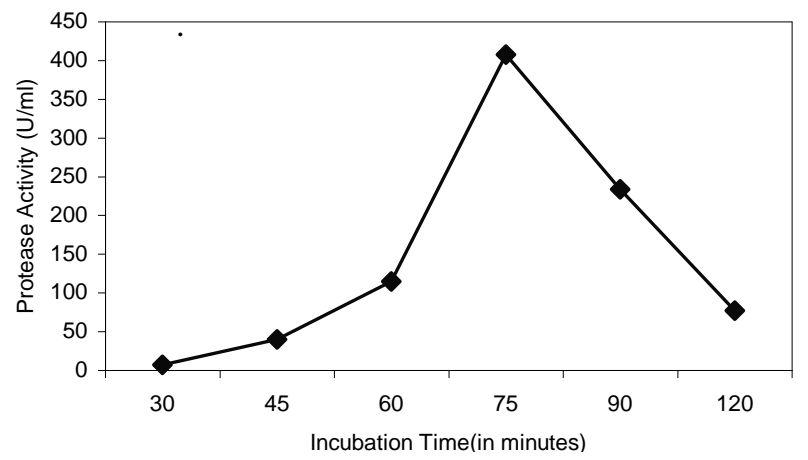

FIGURE 5. EFFECTS OF INCUBATION TIME ON PROTEASE (CRUDE) ACTIVITY BY THE S. BIKINIENSIS (2/BR8).

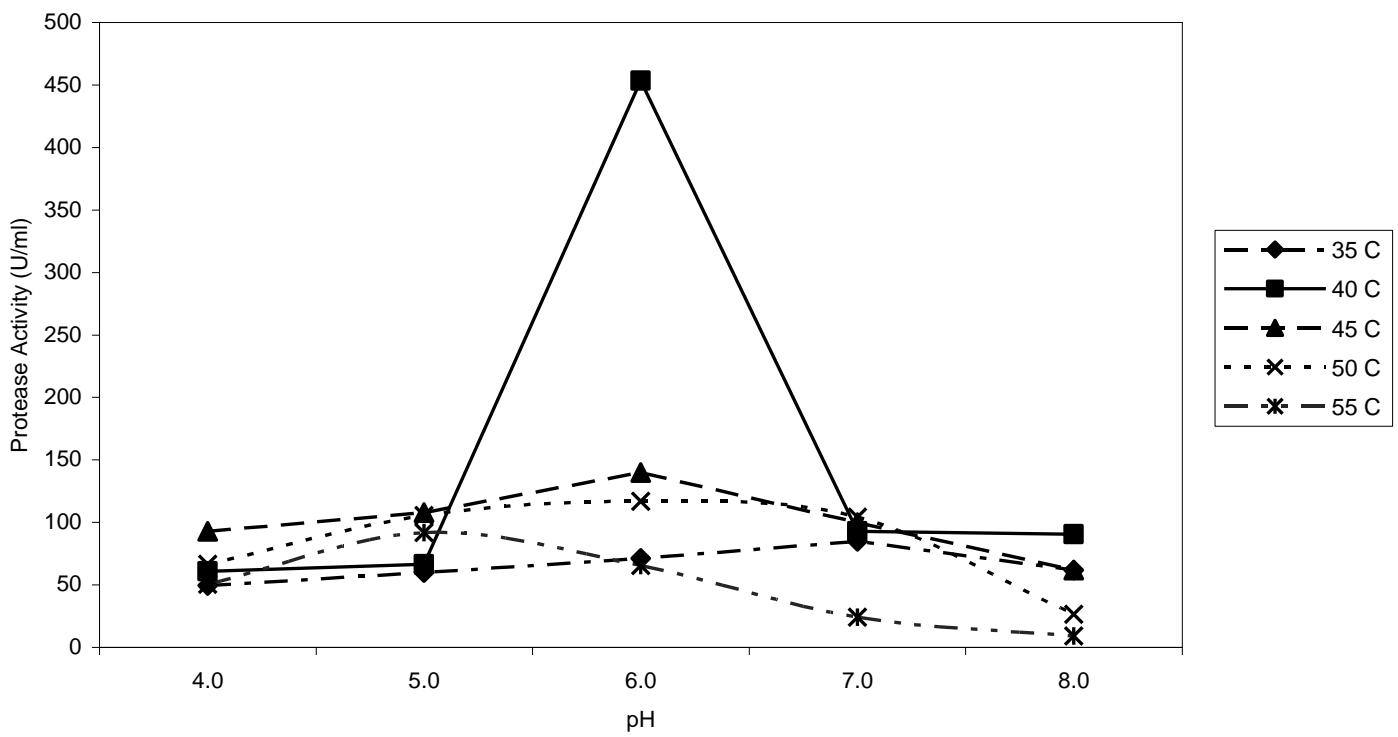

FIGURE 6. EFFECTS OF PH AND TEMPERATURE ON PROTEASE (CRUDE) ACTIVITY BY THE S.BIKINIENSIS (2/BR8).

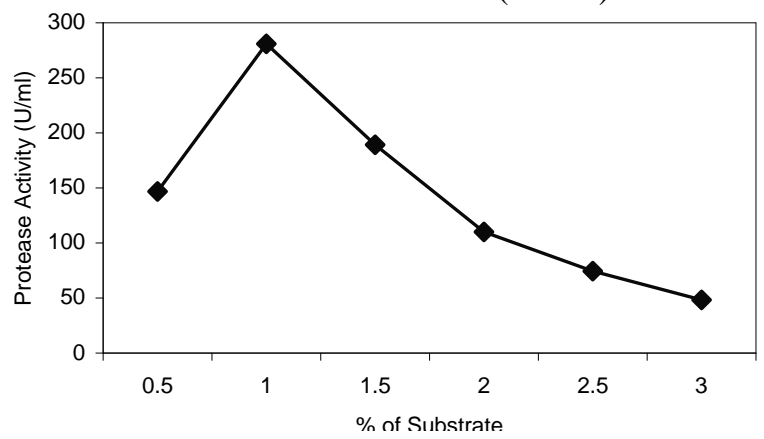

Figure 7. Effects of Substrate concentration on protease (crude) activity by the S.bikiniensis (2/BR8)

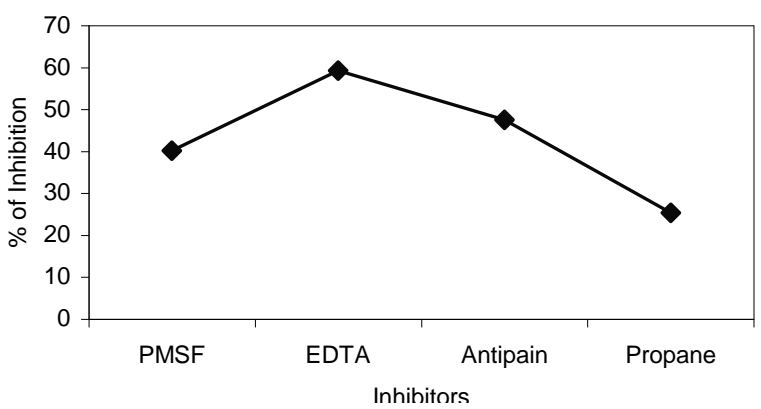

FIGURE 8. EFFECTS OF INHIBITORS ON PROTEASE (CRUDE) ACTIVITY BY THE S.BIKINIENSIS (2/BR8). 


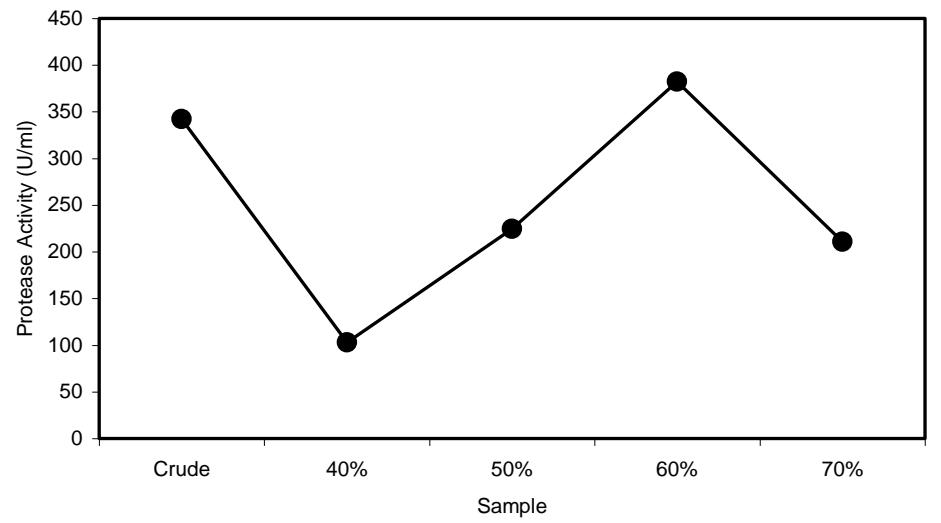

FIGURE 9. ENZYME ACTIVITY OF CRUDE AND PARTIALLY PURIFIED ENZYME OF S. BIKINIENSIS (2/BR8)

\section{REFFERENCE}

ABD RAHMAN, R. N. Z., GEOK, L.P., BASRI, M. AND SALLEH, A.B. 2005. Physical factors affecting the production of organic solvent-tolerant protease by Pseudomonas aeruginosa strain K. Bioresource Technol. 96: 429-436.

AMAR, J. S. K. AND HALVORSON, H.O. 1975. Proteinase activities of Saccharomyces cerevisiae during sporulation. J. Bacteriol. 124: 863869.

AZEREDO, L.A.I D., FREIRE, D.M.G., SOARES, R.M.A., LEITE, S.G.F. AND COELHO, R.R.R. 2004. Production and partial characterization of thermophilic proteases from Streptomyces sp. isolated from Brazilian cerrado soil. Enzyme Microb. Technol. 34: 354-358.

BUCHANAN, R.E AND GIBBONS, N.E. $\left(8^{\text {th }}\right.$ ed). 1974. Bergey's Manual of Determinative Bacteriology. $8^{\text {th }}$ ed. The William and Wilkons Co. Baltimore. pp 12

DAS, F., HOSSAIN, M. T. AND ANWAR, M.N. 2005. Protease production by Bacillus sphaericus . Chittagong Univ.J. Sci. 29: 71-76.

DASTAGER, S. G., DAYANAND, A., Li, W., KIM, C., LEE,J.,PARK, D., TIAN, X AND RAZIUDDIN,Q.S. 2008. Proteolytic activity from an alkali-thermotolerant Streptomyces gulbargensis sp. Nov. Curr Microbiol. 57(6): 638-642.

FERMOR, T. R. AND WOOD. D. A. 1981. Degradation of bacteria by Agricus bisporus and other fungi. Gen. Microbiol. 126: 377-387. 
HAYASHI, K., FUKUSHIMA, D AND MOGI, K.1967. Alkanine proteinase of Aspergillus sojae. Physicochemical properties, amino acid compositions and molecular conformation. Agric.Biol.Chem.31:642-643.

ITO, E. T; PEREIRA, G. V., MIYAGUI, D. T., PINOTTI, M. H. P. AND NEVES, P. M. O. J. 2007. Production of extracellular protease by a Brazilian strain of Beauveria bassiana reactivated on coffee berry borer, Hypothenemus hampei. Braz. Arch. Biol. Technol. 50: 1516-8913.

KALISZ, H. M., MOORE, D. AND WOOD, D. A. 1987. Protein utilization by basidiomycete fungi. Trans. Brit. Mycol. Soc. 86: 519-525

KIM, I.S., KIM, Y.B. AND LEE, K.J. 1998. Characterization of the leupeptininactivating enzyme from Streptomyces exfoliatus SMF13 which produces leupeptin. Biochem. J. 331: 539-545.

MADIGAN, T.M., MARTINKO, M.J., AND PARKER, J. 1997. Brock Biology of Microorganisms, Prentice Hall, Inc.: pp.451-452.

MATTA, H., PUNJ, V. AND KANWAR, S.S. 1997. An immuno-dot blot assay for detection of thermostable protease form Psudomonas sp. AFT-36 of dairy origin. Appl. Microbiol. 25: 300-302.

MEYERS, S.P AND AHEARN, D. G.1977.Extracellular proteolysis by Candida lypolica. Mycologia. 69(3):646-651.

PATKE, D. AND DEY, S. 1998. Proteolytic activity from a thermophilic Streptomyces measporus strain SDP4. Lett Appl. Microbiol. 26: 171174.

RAJAKUMAR, S. 1998. Hydrolysis of chrome-tanned leather wastes and production of alkaline protease BBY. A Penicillium species. International Symposium on Ecology of Fungi, Goa University Goa-403 206, India.

RAMESH, S., RAJESH, M AND MATHIVANAN, N.2009.Characterization of a thermostable alkaline protease produced by Streptomyces fungicidicus MML1614. Bioprocess Biosyst Eng.32:791-800

RAO, M.B., TANKSALE, A.M.,GHATGE,M.S AND DESHPANDA, V.V. 1998. Molecular and biotechnological aspects of microbial proteases. Microbiol Mol Biol Rev. 62(3):597-635.

RIFAAT, H. M., HASSANEIN, S. M., EL-SAID,O.H AND SALEH,S.A.2006. Purification and characterization of extracellular neutral protease from Streptomyces microflavus. Arab J. Biotech. 9(1): 51-60.

SAAD, M.M. AND HODA, H.A. 1997. Purification, crystallization and some enzymatic properties of alkaline protease by Streptomyces venezuelae DMS 4027. National Information and Documentation Centre. Bull. Natt. Res. Cent. (Egypt). 22: 311-321. 
PROTEASE FROM STREPTOMYCES BIKINIENSIS

SEONG, C.N., JO, J.S., CHOI, S.K., KIM, S.W., KIM, S.J., LEE, O.H., HAN, J.M. AND YOO, J.C. 2004. Production, purification, and characterization of a novel thermostable serine protease from soil isolate Streptomyces tendae. Biotechnol. Lett. 26: 907-909.

SHAFEE, N., ARIS, S.N., ABD RAHMAN, R. N. Z., BASRI, M.AND SALLEH, A.B.2005. Optimization of Environmental and Nutritional Conditions for the Production of Alkaline Protease by a Newly Isolated Bacterium Bacillus cereus Strain 146. J. Appl. Sci. Res. 1: 1-8.

SHALINISEN, S. AND SATYANARAYANA, T. 1993. Optimization of alkaline protease production by thermophilic Bacillus licheniformis S40. Ind. J. Microbiol. 33: 43-47.

SHUMI, W., HOSSAIN, M.T. AND ANWAR, M.N. 2004.Isolation and purification of Aspergillus funiculosus G. Smith and its enzyme protease. Pakistan J. Biol. Sci. 7: 312-317.

TREVAN, M. D.2003. In: Biotechnology. The Biological Principles, (Eds. Trevan, M. D., Boffey, S., Goulding, K. H. and Stanburg, P.) Tata McGraw Hill Pub. Co., New Delhi. pp. 155-225.

Manuscript received on 3. 3. 10; Accepted on 24. 5. 10

The Chittagong University Journal of Biological Sciences, Vol.4 ( 1 \& 2): Page No : 153-163 